\title{
日本建築学会構造系論文集ならびに 日本建築学会計画系論文集応募規程
}

（改正 1994年12月12日理事会決 1994年12月13日実施）

1. 内 容

建築に関する学術・技術・芸術についての下記の論文及び質疑钨 論とする。

(1) 投稿論文

a）論文は未発表のものに限る。

“但し， 2 項に記臷するものについては，未発表のものと みなす。

b）論文は建築に関連した内容を有し，次のカテゴリーのいず 九かに該当するものとする。

カテゴリーI 独創性のある萌讳的研究で, 発展性の期待 できるもの。

カテゴリーII 新しい知見を与える有用性, 実用性に豈ん だ実測・実験・铜查等の研究で，信頼性が高 く，学術的，技術的に価值のあるもの

カテゴリーIII 独創性のある理論的または実証的な研究 で, 完成度の高いもの

c）著者は，投稿時にカテゴリーI〜IIのいずれかを申告す 了。

（2）質疑討論は，揭載された論文について，揭载後 1 年以内に投 稿するものとし，誌上にて行う。

2. 既発表のものであっても応基できる䇛囲

(1) 大会学術講演会, 支部研究発表会で発表したもの。

（2）シンポジウム，研究発表会，国際会議等で梗概または資料と して発表したもの。

（3）大学の紀要, 研究機関の研究所報等で部内発表したもの。

（4）国, 自治体，業界，団体からの委託研究の成果報告费。

3. 連統する応募の取扱い

（1）連続して数編応募する予定の場合には，各編がそれぞれ完結 したものとする。この場合の表题は主題を適切に表したものと し、総主題をサフタタイトルとする。

（2）連続した数編を応骑する場合には，さきの編の查読終了後, 䌇編が受理される。

4. 応基盗格

本会会員（個人）とする。

5. 原稿

（1）論文㧍よび啠疑討論は，和文・英文のいずれでもよい。

（2）論文およU゙質疑討論の本文の前に英文要旨およびキーワー ドを添える。

（3）諭文は，刷上り６頁以内を基準とし，超過頁は 4 頁を限度と する。

啠疑討論は，刷上り 2 頁以内とし，超過頁は認めない。

（4）原稿書き方種別および執黍の詳細は，「執筆要領」を参照す る。

（5）最終の版下原稿の作成時, 採用原稿の字句または文章の费き 足し、茟き改めは認められない。

6. 原稿の提出

（1）原稿は, 執篚要領に沿って作成したもの 3 通（コビー）を提 出する。

操用決定後，最終の版下原稿を 1 通提出する。

(2) 原稿の提出に際しては,「論文」「質疑討論」の区別, 查読希 望の論文のカテゴリーおよU゙下記の查読希望曹門研究部門名 を所定の用紙に明示する。

「材料施工」「構造」「防火」「海洋」「情報システム技術」「摆 境工学」「建筑計画」「都市計画」「農村計画」「建築経済·住 宅問題」「建筑歴史・意匠」「教青」

なお，原則として「材料施工」「辢造」「防火」「海洋」「情報 ジステム技術」は構造系論文集, 「環境工学」「建築計画」「都 市計画」「農村計画」「建䓩経消・住宅問題」「建築歴史・意匠」 「教育」は計画系論文集に揭载されるが,他系に揭载を希望する 場合は所定椵に明示する。

（3）原稿の提出期日は，各月10日締めとする。

（4）原秴が本会に到着した日を原稿受理日とする。原稿受理日が 当月の10日以前の原稿を当月より查読を開始する原稿とする。 ただし、内容の訂正などを指摘された原稿で本会発送日より 2 月以内に改訂原稿が返送されない㘯合は, 政初の受理日は 無効とし、改訂原稿が本会に到着した日を原稿受理日とする。

（5）原稿提出の際，データベース登録原稿を添付寸る。

7. 論文の採否

（1）論文の採否は本会論文集委員会が查謊の判定基準に基づい て決定し，著者に通知する。
（2）論文については查読の判定基準は以下の通りである。

a . 全般的な查読の項目

$\mathrm{a}-1$ ) 提起した問題，導入した概念や方法，発見した事 実や法則の新規・独創性および得られた結果の学術 的および技術的な新規性・有用性。

$\mathrm{a}-2$ ) 論旨, 論拠の妥当性・明快性・方法（実験, 調查 等)，とその結果の信頼性・再現性および研究展望, 研究の位置付けの適切さ。

a -3）表現，用鯃や関連文献引用の適切さおよび商業主 義からの中立性

b ．諭文を各カテゴリーに応して，つぎの基準で査読する。

b-1） カテゴリーIの論文については，萠芽性，発展性、 独創性を重視し，その信頼性と完成度については評 価するが過度に重視しない。

b-2）カテゴリーIIの論文については，学術的および技 術的有用性，実用性を重視し，その新規性と信頼性， 完成度についでも評価する。

b-3）カテゴリーIIIの論文については, 独創性, 学術的 価値性・有用性, 信頼性を重視し, 完成度も評価す

（3）論文のカテゴリー区分は，查読時の評価判定に用い，論文集 への揭載時には記载しない。

（4）查読の結果，「採用」の論文には，採用決定日を明記する。

（5）查読の結果，「再查境」の場合は, 修正された原稿について 改めて查梳を行う。

（6）查読の結果が「不採用」の勚合で，その「不採用」の理由に 対して，論文提出者が明らかに不当と考えた場合には，不当と する理由を明記して、本会論文集委員会委員長あてに異竓申立 てをすることができる。

8. 質疑狽論の採否

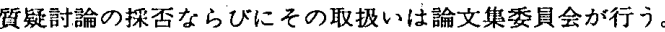

9. 著作権

（1）揭截論文・質疑討論の著作梅は著者に属する。

本会は絧集出版権をもつものとする。

（2）著者は揭阵論文・質疑瑼論の複写権を本会に委託するものと する。丶)

10. 骿文集の体裁

諭文集の刷上り体裁を B 5 判にするために，採用となった熶終の 版下原稿を縮小した時，本文が 8 ポイント程度となるようにする。

11. 登载料・超過頁料・カラー印刷揭溨料

採用された論文は本会論文集登戟料として，10，000円を徽する。 本会の刷上り頁数が基準頁数の 6 頁を超過した場合は超過頁料と して 1 頁につき 20,000 円を徽する。

また,カラー印刷による揭载は, 著者の申し出により行うことか できる。カラー印別に要する費用は著者の負担とする。

12. 別 刷

論文および啠疑討論の別刷は有料にて硕布する。

13. 送 付 先

論文, 質疑討論の原稿および異議申立ての文旂は, 下記宛に送付 する。

于108 東京都港区艺 5 丁目 26 番 20 号

日本建築学会 論文集委貝全

付表 論文の評洒項目

\begin{tabular}{|c|c|c|c|c|c|}
\hline \multicolumn{3}{|c|}{ カテゴリー } & I & II & III \\
\hline 独 & 創 & 性 & 0 & 1 & 0 \\
\hline 萌 & 芽 & 性 & 0 & & \\
\hline & 展 & 性 & 0 & & \\
\hline & 约有 & & & 0 & \\
\hline & 约位 & 性・有用性 & & 0 & 0 \\
\hline 信 & 頼 & 性 & 2 & 0 & 0 \\
\hline 完 & 成 & 度 & ? & 0 & 0 \\
\hline
\end{tabular}

[凡例]

○謤価の対象とする

語評価するが, 過度に重視しない

注）著者が複写権を日本建築学全に委託しても自分の論文を自らの 用途のために䙓写することについては，制限はない。 